$14^{\text {th }}$ Conf. Agric. Develop. Res., Fac. of Agric., Ain Shams Univ., March, 2019, Cairo, Egypt

Special Issue, 27(1), 239 - 257, 2019

Website: http://strategy-plan.asu.edu.eg/AUJASCI/

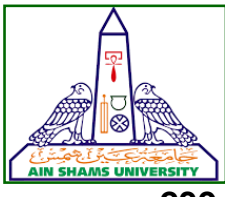

\title{
IMPACT OF PLANT GROWTH-PROMOTING RHIZOBACTERIA ON COW- PEA GROWTH PERFORMANCE AND ROOT DISEASES CONTROLLING UNDER GREENHOUSE CONDITIONS
}

\author{
Zaghloul, R.A. ${ }^{1}$; Abou-Aly, H.E. ${ }^{1}$; Abdel-Rahman, H.M. ${ }^{1}$ and Hassan, M.A. ${ }^{2}$
}

1. Agric. Microbiology Dept., Fac. of Agric., Banha Univ., Egypt

2. Agric. Microbiology Dept., Fac. of Agric., South Valley University, Egypt

Received 3 February, 2019, Accepted April, 2019

\begin{abstract}
This study was executed during two successive seasons 2014 and 2015 for evaluating the effect of inoculation with Bradyrhizobium sp, Bacillus megaterium, Bacillus circulans, Glomus macrocarpum and Pseudomonas fluorescens on infection percentage, enzymatic activity, growth characteristics, total phenol, peroxidase and polyphenol oxidase activity in presence or absence of Fusarium oxysporum in sterilized or non- sterilized soil under greenhouse condition. The obtained results observed that the tested strains showed suppression for F. oxysporum in vitro. Similar results were obtained under greenhouse experiment where the inoculation of soil with biofertilizers strains in presence of $P$. fluorescens showed the lowest records of infection percentage as well as the higher values of enzymatic activity, growth characteristics, total phenol, peroxidase and polyphenol oxidase activity compared to full dose of chemical fertilizers treatment. This study provides evidence for diminishing the adverse evolved from the continues application of chemical fertilizers in high doses and replacing it (at least partially) through biofertilizers and biocontrol application.
\end{abstract}

Keywords: Cowpea, Growth-promoting, Rhizobacteria, Root diseases greenhouse conditions

\section{INTRODUCTION}

Cowpea (Vigna unguiculata L. Walp) is a food legume of significant economic importance worldwide. Cowpea diseases induced by species of pathogens belonging to various pathogenic groups (fungi, bacteria, viruses, nematodes, and parasitic flowering plants) (Sendhilvel et al 2005). Disease control remains one of the most challenging issues to be addressed, which is especially true for cowpea considering the largely undefined area of cowpea self defense mechanisms.

Because of inappropriate applications of chemical fertilizers during continuous crop cultivation, many countries suffer from problems such as pollution of agricultural lands, water resources, and soil salinization. In an attempt to reduce these chemical inputs and raise soil quality as well as improve crop production, biotechnological practices such as application of biofertilizers have been investigated (Talaat and Abdallah, 2008 and PaungfooLonhienne et al 2019). Moreover, chemical fungicides application is the conventional strategy used for managing damping off for over 50 years. However, fungicides have shown some promising results in controlling damping off, fungicide residues could lead to environmental pollution and human health hazards.

The dynamic nature of soil is a direct manifestation of soil microbes, bio-mineralization, and synergistic co-evolution with plants. Plant growth promoting rhizobacteria (PGPR) are the rhizospheric bacteria that possess potential to enhance the plant growth in various ways through phosphate solubilization, nutrient cycling, siderophores production, etc. The potential applicability of PGPR is steadily increasing in agriculture because it offers a promising approach to replace the use of chemical fertilizers, pesticides, and other supplements. Recent progress in our understanding enhances on the diversity of PGPR in the rhizosphere along with their colonization ability and mechanism of action that would facilitate their wider application in the management of sustainable agricultural crop production. Further, PGPR is being functioning as a connecting link between plants and microbes 
that could express antagonistic and synergistic interactions with microorganisms and the soil (Shukla, 2019).

Biocontrol approaches may help to develop ecofriendly strategies for managing this disease in cowpea seedlings. Biological control represents both the oldest and youngest technology for the control of plant diseases and pest (Akinbode and Ikotun, 2008 and Nandi et al 2013). Most people agree that agriculture could not have begun without the benefits of naturally occurring biological controls. Yet modern biological control achieved with introduced microorganisms is still in its infancy. The use of fluorescent pseudomonads is gaining importance for plant growth-promotion and biological control. Fluorescent pseudomonads could reduce disease severity in several crop plants through induced resistance phenomenon (Thahir et al 2012). Induced systemic resistance in crop plant is characterized by the induction of host defense responses including, defense related enzymes synthesis and phenolic accumulation. In this context, Pseudomonas fluorescens is plant growth promoting rhizobacterium (PGPR) and lives in the plant rhizosphere. More specifically, P.fluorescens strains have received particular attention throughout the global science because of excellent root colonizing ability and their capacity to produce a wide range of enzymes and metabolites that help plant to withstand under varied biotic and abiotic stress conditions (Mayak et al 2004 and Hossam and Zayed, 2015). In addition, some reports have shown that PGPR have a strong stimulatory impact on the mycorrhizal establishment, growth and function (Va'zquez et al 2000 and Artursson et al 2006).

Most agricultural crops are colonized by arbuscular mycorrhizal fungi (AMF). In this symbiotic association, host plants provide the fungi with carbohydrates and in return receive mineral nutrient. AMF can enhance growth of crop plants through increasing nutrient uptake, particularly $P$ (Ryan and Angus, 2003).

Phosphate solubilizing bacteria (Bacillus megaterium) may release several organic acids including oxalic, citric, butyric, malonic, lactic, succinic, malic, gluconic, acetic, fumaric and ketogluconic, which solubilize phosphate and micronutrients and subsequent reduction in soil $\mathrm{pH}$ (Ahmed, 2010). The release of $\mathrm{K}$ form the feldspar was obviously affected by the role played by these bacteria ( $\mathrm{Ba}$ cillus circulans) which attached to feldspar surface and greatly accelerated the weathering of some minerals with the release of great amounts of both water soluble and amorphous. A lot of energy is released as a result of biodegradation of aluminosilicate structures and the bacteria, which play role in the biodegradation and have the ability to grow on it.

Most plants in natural conditions form a symbiosis with arbuscular mycorrhizal fungi (AM) which has distinguishing importance due to great capability to increase plant growth and yield under different conditions (Zayed et al 2013 and Eissa et al 2015). Many studies have demonstrated that arbuscular mycorrhizal (AM) symbiosis is often alleged to improve plant resistance to water salinity stress through the alteration of plant physiology and expression of some plant genes, help in water regulation of plants by extending their hyphae toward the available moisture zones for continuous water absorption and translocate it to plants (Giri et al 2004). In addition, AM association can affect the host plants in terms of stomatal movement and photosynthesis of leaves and increase the chlorophyll concentration. Different studies have indicated that $\mathrm{AM}$ plants are frequently more tolerant to salt stresses than non-AM plants (Al-Karaki, 2006), with only few exceptions (Ouziad et al 2006) .This investigation has been conducted to evaluate the effect of using plant growth promoting rhizobacteria (Pseudomonas fluorescens), phosphate dissolving bacteria (Bacillus megaterium) and potassium releaser bacteria (Bacillus circulans) and AM fungi on the productivity and quality of cowpea for diminishing the adverse evolved from the continues application of chemical fertilizers or pesticides in high doses.

\section{MATERIALS AND METHODS}

An experiment was executed during two successive seasons, 2014 and 2015, at Faculty of Agriculture, South Valley University, Qena Governorate, Egypt to study the effect of biofertilizers and mineral fertilizers as well as their interactions on the growth and yield components.

\section{Cowpea seeds}

Seeds of cowpea (Vigna unguiculata (L.) Walp) Creeam 7 were obtained from Vegetable Crops Research Dept., Horticultural Institute, Agriculture Research Centre, Giza, Egypt.

\section{Chemical fertilizers}

Chemical fertilizers were got from regional market in Qena, Egypt. 


\section{Biofertilizers}

Biofertilizers contain four microbial strains namely Bradyrhizobium sp, Bacillus megaterium, Bacillus circulans, and Glomus macrocarpum were kindly obtained from Microbiological Resources center, Cairo MIRCEN, Ain Shams University, Egypt.

\section{Biocontrol agent strain}

Biocontrol agent strain Pseudomonas fluorescens was kindly obtained from Microbiological Resources center, Cairo MIRCEN, Ain Shams University, Egypt.

\section{Pathogenic fungi strain}

Fusarium oxysporum was kindly obtained from Microbiological Resources center, Cairo MIRCEN, Ain Shams University, Egypt.

\section{Experimental soil}

Experimental soil was subjected to chemical and mechanical examinations as stated by the method explained by Page et al. (1982). Mechanical and chemical soil features are tabulated in Table (1).

\section{Antagonistic activity of biofertilizer and biocon- trol strains}

Antagonistic effect of the biofertilizers (Bradyrhizobium sp., Bacillus megaterium and Bacillus circulans) and biocontrol strain (Pseudomonas fluorescens) against soil-borne pathogenic fungi $F$. oxysporum was studied in vitro under laboratory conditions.

The dual culture technique as described by Paulitz et al (1992) and Landa et al (1997) was used and the fungal culture was grown on potato dextrose agar medium (PDA). F. oxysporum was initially grown in Petri dishes containing PDA medium and incubated at $28^{\circ} \mathrm{C}$ for $72 \mathrm{hrs}$. Then 0.5 $\mathrm{cm}$ disks were cut from the edge of the active growth colonies of each fungus. One disk of each fungus was transferred to the center or in one half of Petri dish containing the previous medium. Bacterial strains under investigation were added with circular shape linearly in the other half dish.

\section{Greenhouse experiment}

A pot experiment was designed to study the effect of biofertilization combined with biocontrol agents on cowpea growth performance, infection percentage, microbial enzymes activity in soil, total phenol, peroxidase and polyphenol oxidase activities in leaves of cowpea when sowing in infested and un-infested soil with Fusarium oxysporum. This experiment was carried out in sterilized and non-sterilized soil in plastic pots containing sandy loam soil ( $10 \mathrm{~kg} / \mathrm{pot})$.

Table 1. Mechanical and chemical analyses of the experimental soil.

\begin{tabular}{|c|c|c|c|c|c|c|c|c|c|c|c|c|c|c|c|c|c|c|c|c|c|c|c|c|}
\hline \multirow{4}{*}{\multicolumn{2}{|c|}{ 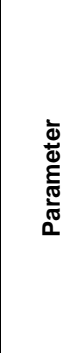 }} & \multicolumn{4}{|c|}{ Mechanical analysis } & \multicolumn{19}{|c|}{ Chemical analysis } \\
\hline & & \multirow{3}{*}{ 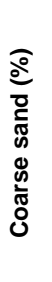 } & \multirow{3}{*}{ 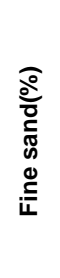 } & \multirow{3}{*}{ 冚 } & \multirow{3}{*}{$\frac{\widehat{\circ}}{\frac{\pi}{0}}$} & \multirow{3}{*}{ 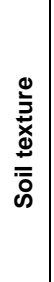 } & \multirow{3}{*}{ 동 } & \multirow{3}{*}{ 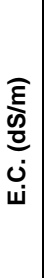 } & \multirow{3}{*}{ 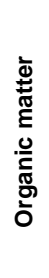 } & \multirow{3}{*}{ 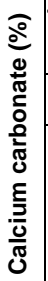 } & \multicolumn{6}{|c|}{$\begin{array}{l}\text { Total and available macronutrients } \\
\qquad(\mathrm{ppm})\end{array}$} & \multirow{2}{*}{\multicolumn{4}{|c|}{$\begin{array}{c}\text { Soluble cations } \\
\mathrm{meq} / 1\end{array}$}} & \multirow{2}{*}{\multicolumn{4}{|c|}{$\begin{array}{c}\text { Soluble anions } \\
\mathrm{meq} / 1\end{array}$}} \\
\hline & & & & & & & & & & & \multicolumn{2}{|c|}{$\mathbf{N}$} & \multicolumn{2}{|c|}{$\mathbf{P}$} & \multicolumn{2}{|c|}{$\mathbf{K}$} & & & & & & & & \\
\hline & & & & & & & & & & & 횽 & 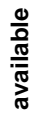 & 푱 & $\begin{array}{l}\frac{0}{0} \\
\frac{\pi}{\frac{\pi}{\pi}} \\
\frac{\pi}{2}\end{array}$ & $\begin{array}{l}\text { बूँّ } \\
\text { 。 }\end{array}$ & $\begin{array}{l}\frac{0}{0} \\
\frac{\pi}{\pi} \\
\frac{\pi}{\pi}\end{array}$ & $\begin{array}{l}+\neq \\
\text { ○ึ }\end{array}$ & $\stackrel{+}{ \pm 0}$ & $\stackrel{+\pi}{\mathbf{2}}$ & \pm & ᄋ̊ำ & $\mathcal{O}_{+}^{\infty}$ & $\overline{0}$ & '̊ \\
\hline \multirow{2}{*}{ 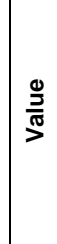 } & $\frac{+}{\stackrel{+}{N}}$ & $\underset{\infty}{\stackrel{N}{\infty}}$ & ه̊ & $\stackrel{\hat{f}}{\dot{j}}$ & 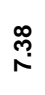 & \multirow{2}{*}{ 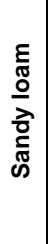 } & $\underset{\substack{\infty\\
}}{\stackrel{\infty}{\infty}}$ & 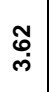 & $\frac{N}{0}$ & స్ల్ర & ઠి & $\stackrel{\overbrace{}}{\curvearrowright}$ & สิ & $\stackrel{\oplus}{\oplus}$ & ద్ని & $\stackrel{p}{=}$ & స్లి & $\begin{array}{l}\text { D } \\
\text { N }\end{array}$ & $\begin{array}{l}\stackrel{2}{2} \\
\stackrel{0}{0}\end{array}$ & 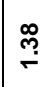 & 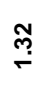 & ' & $\begin{array}{l}\text { o్ } \\
\stackrel{0}{0}\end{array}$ & i̊ \\
\hline & 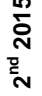 & 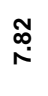 & ָ̃ & $\underset{\dot{I}}{\dot{q}}$ & $\stackrel{\infty}{\stackrel{\infty}{r}}$ & & $\bar{\infty}_{\infty}$ & స్ & $\frac{m}{0}$ & ঙุ & ి్సి & $\begin{array}{l}\infty \\
\infty \\
\infty\end{array}$ & ลิ & น̊ำ & ద్ని & $\stackrel{\mathscr{m}}{\stackrel{m}{m}}$ & $\frac{\infty}{\infty}$ & 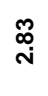 & $\begin{array}{l}\stackrel{1}{0} \\
\stackrel{0}{0}\end{array}$ & 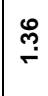 & 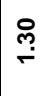 & ' & 惢 & in \\
\hline
\end{tabular}




\section{Experimental design}

The treatments were distributed in greenhouse using randomized complete design (Fig. 1). Three replicates of each treatment were used. Plastic pots (30 $\mathrm{cm}$ in diameter) were sterilized by immersing in $5 \%$ formalin solution for 15 minutes and covered overnight with plastic sheets, then left to dry in the open air. Soil sterilization was carried out by autoclaving at $15 \mathrm{1b} / \mathrm{inch}^{2}$ for two hours.

Preparation of pathogens inoculum and soil infestation

The inoculum of $F$. oxysporum was prepared by growing in conical flask $(500 \mathrm{ml})$ containing 250 $\mathrm{ml}$ potato dextrose broth medium (Mac Faddin, 1985). The flask was inoculated with $0.5 \mathrm{~cm}$ diameter agar disc bearing mycelium of the fungus, and then the flask was incubated at $28^{\circ} \mathrm{C}$ for two weeks. After incubation period, growth was decanted and mycelial mat was blended in a warring blender. The spores' density was counted using a haemocytometer slide and adjusted to contain about $10^{7}$ spore/ml as recommended by (Zaghloul et al 2007).

Soil was infested with the inoculum by mixing $100 \mathrm{ml}$ of adjusted spore suspension per $\mathrm{Kg}$ soil. Then pots were carefully irrigated and kept under greenhouse conditions for 7 days to activate the fungi before planting.

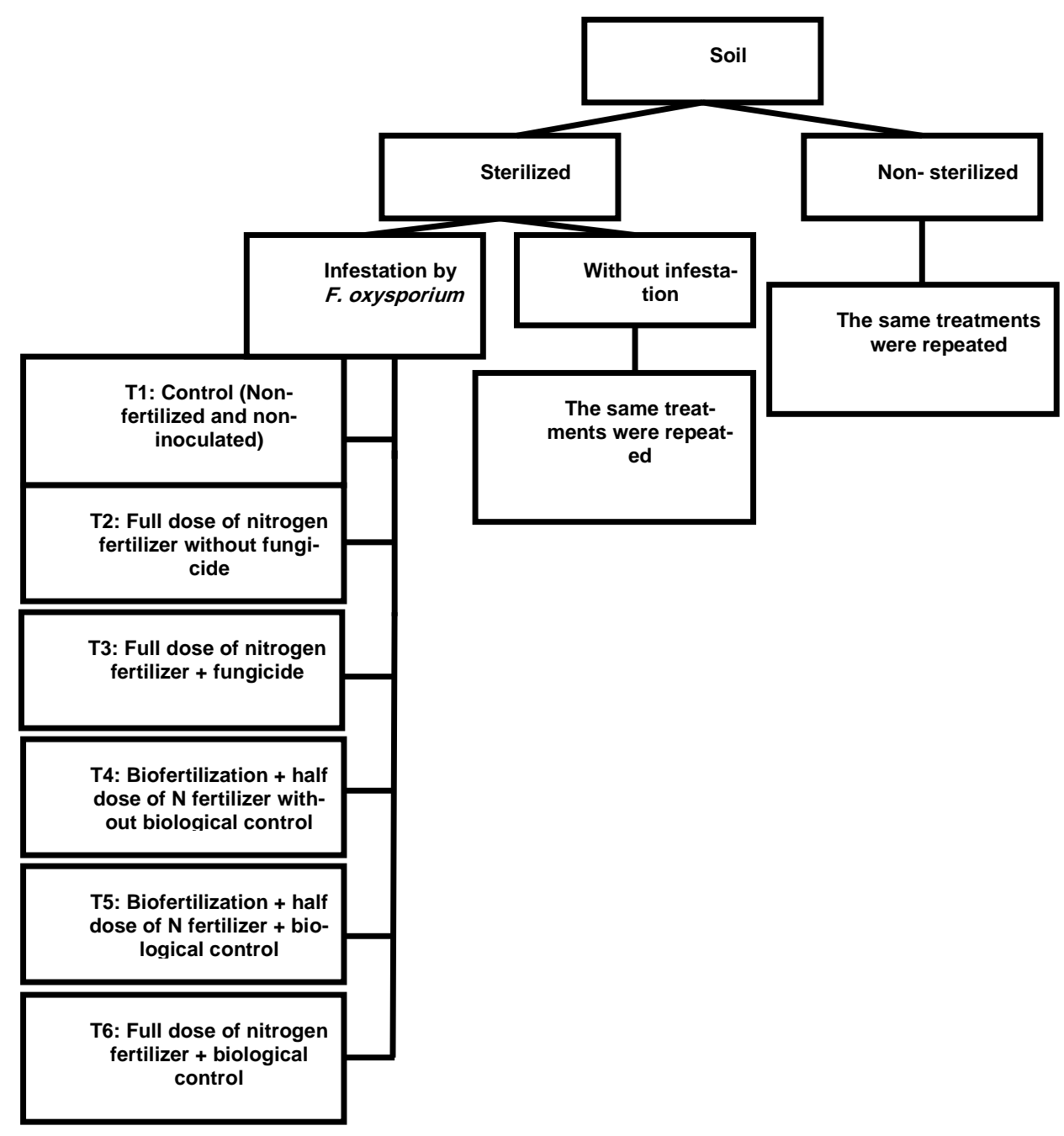

Fig1. Experimental design. 


\section{Preparation of biofertilization and biocontrol inoculants}

For preparation of $B$. circulans inoculum, the Alexandrov medium (Zahra, 1969) was inoculated with $B$. circulans and then incubated at $30^{\circ} \mathrm{C}$ for 3 days. For preparation of $B$. megaterium inoculum, Bunnt and Rovira medium modified by AbdelHafez (1966) was inoculated with $B$. megaterium var phosphaticum, and then incubated at $30^{\circ} \mathrm{C}$ for 3 days. For preparation of Ps. fluorescens inoculum, King's broth medium (King et al 1954) was inoculated with Ps. fluorescens and then incubated at $30^{\circ} \mathrm{C}$ for 3 days. For preparation of bradyrhizobial inoculum, yeast mannitol broth medium (Vincent, 1970) was inoculated with effective strain (Bradyrhizobium sp.), then incubated at $32^{\circ} \mathrm{C}$ for 7 days. For preparation of Glomus macrocarpum inoculum, pots of $30 \mathrm{~cm}$ in diameter were filled with autoclaved sandy loam soil. The soil of each pot was inoculated with AM fungus $G$. macrocarpum. Five onion seedlings were transplanted in each pot as a host plant. After 14 weeks, spores of AM were collected from rhizosphere and roots of onion and extracted by wet sieving (Gerdemann and Nicolson, 1963). AM spores were counted by the method described by Musandu and Giller (1994).

\section{Fungicide seed dressing}

Cowpea seeds were dressed with Rizolex-T $50 \%$ at the recommended dose $(3 \mathrm{~g} / \mathrm{kg}$ of seeds) then sown in infested soil to serve as a comparison treatment.

\section{Cultivation process}

Three kg soil were put in each pot, before cultivation, cowpea seeds were soaked by dipping in mixture of gum Arabic (20\%) as an adhesive for inocula of cell suspension of each Bradyrhizobium $\mathrm{sp}\left(\mathrm{l} \mathrm{ml}\right.$ contains about $\left.1 \times 10^{9} \mathrm{cfu}\right)$ for $30 \mathrm{~min}$. $B$. megaterium var phosphaticum $\left(6 \times 10^{9} \mathrm{cfu} / \mathrm{ml}\right), B$. circulans $\left(4 \times 10^{8} \mathrm{cfu} / \mathrm{ml}\right)$, Ps. fluorescens H2 (1 $\mathrm{x} 10^{9} \mathrm{cfu} / \mathrm{ml}$ ) for 60 minutes before transplanting. The same prepared inocula were added to the pots three times (every month) throughout the growing season at a rate of $100 \mathrm{ml} \mathrm{pot}^{-1}$. Regarding the mycorrhizal treatments, Glomus macrocarpum strain was used at a rate of 500 - 600 spores/pot as soil treatment. After soaking the seed spread in plates and allowed to air drying before sowing. The control seeds were soaked by the same manner, but in the corresponding media without inocula. Chemical fertilizers were supplemented with either a full dose of inorganic nitrogen fertilizer $40 \mathrm{Kg}$ $\mathrm{N} /$ fed or a half dose of $\mathrm{N}$ - fertilizer as ammonium sulphate $(20.5 \% \mathrm{~N})$. While inorganic phosphorus fertilizer $30 \mathrm{Kg} P / f e d$. as calcium super phosphate $\left(15.5 \% \mathrm{P}_{2} \mathrm{O}_{5}\right)$ and $40 \mathrm{Kg} \mathrm{K} / \mathrm{fed}$. as potassium sulphate $\left(48 \% \mathrm{~K}_{2} \mathrm{O}\right)$, respectively were added for all treatments. Other cultural practices were carried out according to the recommendations of Egyptian Ministry of Agriculture.

\section{Determinations}

Rhizoshpere of three plants from each pot were taken at random after 60 days from sowing for enzymes activity determinations. The parameters estimated namely diseases assessment (infection percentage and disease suppersion), enzymes activity (dehydrogenase, nitrogenase and phosphatase) were measured in rhizosphere soil samples, disease severity (DS), resistance enzyme activities in plants (total phenol, peroxidase assay and polyphenol oxidase), plant growth characteristics (plant height $(\mathrm{cm})$, number of branches, number of leaves/ plant, dry weight (gm) and fresh weight (gm) were determined.

\section{Statistical analysis}

Statistical analysis was carried out according to Snedecor and Cochran (1989). The differences between the means value of various treatments were compared by Duncan's multiple range test (Duncan's, 1955).

\section{RESULTS AND DISCUSSIONS}

Efficiency of biofertilization and biocontrol agent on cowpea growth performance and controlling of root diseases under greenhouse condition.

The main objective of this study is to evaluate the efficiency of cowpea plant inoculated with Bradyrhizobium sp., Bacillus megaterium, Bacillus circulans and Glomus macrocarpum combined with Pseudomonas fluorescens on infection percentage, enzymatic activity, growth characteristics, total phenol, peroxidase and polyphenol oxidase activity in presence or absence of Fusarium oxysporum in sterilized or non- sterilized soil.

Initially, antagonistic effects of Bradyrhizobium sp., B. megaterium, B. circulans and $P$. fluorescens against $F$. oxysporum was achieved in vitro under laboratory conditions. The obtained results in Fig. 2 
indicated that the tested strains showed suppression for $F$. oxysporum. Such suppression zones may be likely due to the production of antibiotic substances, HCN, siderophores and/or phytoalexins which acts against plant pathogenic microorganism by biofertilizer strains and $P$. fluorescens. (Loper and Gross, 2007, Killani et al 2011, and Pankaj et al 2012).

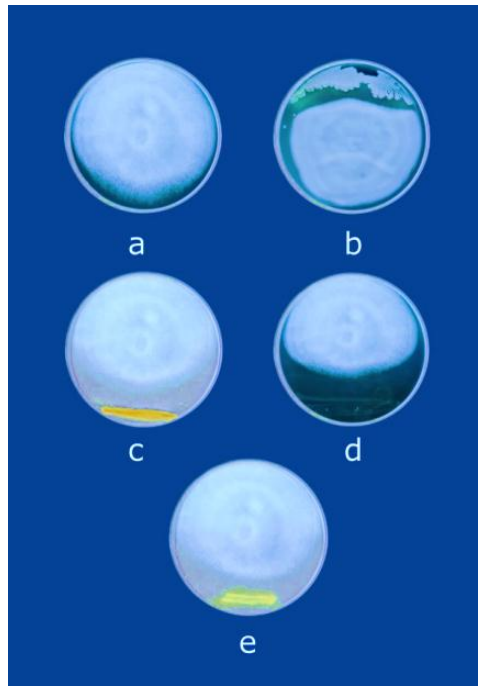

Fig 2. Antagonistic effect of Bacillus megaterium, Bacillus circulans, Bradyrhizobium sp. and Pseudomonas fluorescens against Fusarium oxysporum.

a: Fusarium oxysporum. b: Bacillus megaterium + F. oxysporum. c: Bacillus circulans + F. oxysporum. d:Pseudomonas fluorescens + F. oxysporum. e:Bradyrhizobium sp. + F. oxysporum.

\section{Disease severity percentage of cowpea.}

Data presented in Table (2) showed that nonsterilized soil treatments have the lower percentages of Fusarium infection appeared rather than sterilized ones. This result is likely be due to the presence of indigenous PGPR in non-sterilized soil.

In addition, obtained results observed that in un-infested soil there are no infected plants showed in whether non-sterilized or sterilized soil treatments. While in infested soil, the rate of infection ranged between $20-73.33 \%$ and $20-100 \%$ in non-sterilized and sterilized soil treatments, respectively.

Inoculation of soil with biofertilizers strains in presence of $P$. fluorescens showed the lowest records of infection percentage. While the highest records of infection percentage showed in infested soil with $F$. oxysporum individually. These records are in harmony with Parmar and Dadarwal (1999) who reported that the presence of Pseudomonas $\mathrm{sp}$ induce the synthesis of flavonoids by roots of common bean in experiment of co-inoculation with rhizobia.

Cowpea inoculation with biofertilizer strains (Bacillus megaterium, Bacillus circulans, Bradyrhizobium sp., and Glomus macrocarpum) significantly decreased the percentage of Fusarium infection compared to the un-inoculated ones. While, disease suppression increased with cowpea inoculated with biofertilizer strains.

Table 2. Effect of biofertilization and Pseudomonas fluorescens inoculation on Fusarium infection, disease suppression and disease severity percentage of cowpea.

\begin{tabular}{|c|c|c|c|c|c|c|c|c|c|c|c|c|}
\hline & \multicolumn{6}{|c|}{ Non - sterilized soil } & \multicolumn{6}{|c|}{ Sterilized soil } \\
\hline & \multicolumn{3}{|c|}{ Without infested } & \multicolumn{3}{|c|}{ infested } & \multicolumn{3}{|c|}{ Without infested } & \multicolumn{3}{|c|}{ infested } \\
\hline & $\begin{array}{c}\text { Infection } \\
\%\end{array}$ & $\begin{array}{c}\text { Suppres- } \\
\text { sion \% }\end{array}$ & $\begin{array}{c}\text { Disease } \\
\text { severity } \\
\%\end{array}$ & $\begin{array}{c}\text { Infec- } \\
\text { tion } \\
\% \\
\end{array}$ & $\begin{array}{c}\text { Suppres- } \\
\text { sion } \%\end{array}$ & $\begin{array}{c}\text { Disease } \\
\text { severity } \\
\%\end{array}$ & $\begin{array}{c}\text { Infection } \\
\%\end{array}$ & $\begin{array}{c}\text { Suppres- } \\
\text { sion } \%\end{array}$ & $\begin{array}{c}\text { Disease } \\
\text { severity } \\
\%\end{array}$ & $\begin{array}{c}\text { Infection } \\
\%\end{array}$ & $\begin{array}{c}\text { Suppres- } \\
\text { sion } \%\end{array}$ & $\begin{array}{c}\text { Disease } \\
\text { severity } \\
\%\end{array}$ \\
\hline T1 & 0 & 100 & 0 & 73.3 & 13.3 & 56.54 & 0 & 100 & 0 & 100 & 0 & 100 \\
\hline T2 & 0 & 100 & 0 & 53.3 & 46.7 & 38.21 & 0 & 100 & 0 & 73.3 & 26.7 & 68.22 \\
\hline T3 & 0 & 100 & 0 & 26.7 & 73.3 & 15.03 & 0 & 100 & 0 & 46.7 & 53.3 & 20 \\
\hline T4 & 0 & 100 & 0 & 33.3 & 66.7 & 25 & 0 & 100 & 0 & 40 & 60 & 40 \\
\hline T5 & 0 & 100 & 0 & 20 & 80 & 16.44 & 0 & 100 & 0 & 20 & 80 & 31.44 \\
\hline T6 & 0 & 100 & 0 & 20 & 80 & 18.22 & 0 & 100 & 0 & 20 & 80 & 38.22 \\
\hline
\end{tabular}

For more details about T1-T6 see Fig 1. 
These results were observed in presence or absence of Pseudomonas fluorescens. This result is in agreement with Jacob (2013).

The mechanisms of biological control of plant pathogens by antagonistic bacteria and fungi have been the subjects of many studies in the past two decades (Janisiewicz et al 2000). Mechanisms of biocontrol of soil-borne pathogens are as a result of the direct action of antagonists on plant pathogens, through antibiosis, predation or parasitism, induced resistance of the host plant, and direct competition for space and limited resources (Janisiewicz et al 2000). These mechanisms reduce the infection level and bring about the desired results. Linderman (2000) reported that shifts in the microbial community structure and the resulting microbial equilibria can influence the growth and health of plants. It means that plant beneficial microorganisms are of interest for application in agriculture as bio-fertilizers

It is importance to mention that there are several mechanisms by which PGPR inhibit soil-borne pathogen including the iron-chelating siderophores, antibiotics and $\mathrm{HCN}$, which reduce the population of root pathogenic fungi. As well as, PGPR have also shown promise as a potential biological control agent for many soil-borne root diseases (Gupta et al 1995 and Niranjan et al 2005).

Mechanisms of biocontrol may be competition or antagonisms; however, the most studied phenomenon is the induction of systemic resistance by these rhizobacteria in the host plant (Ramamoorthy et al 2001 and Niranjan et al 2005). PGPR control the damage to plants from pathogens by a number of mechanisms including: out-competing the pathogen by physical displacement, secretion of siderophores to prevent pathogens in the immediate vicinity from proliferating, synthesis of antibiotics and variety of small molecules that inhibit pathogen growth, production of enzymes that inhibit the pathogen and stimulation of the systemic resistance in the plants. PGPR may also stimulate the production of biochemical compounds associated with host defense. Enhanced resistance may be due to massive accumulation of phytoalexins, phenolic compounds, increases in the activities of PR-proteins, defense enzymes and transcripts, and enhanced lignification. Biocontrol may also be improved by genetically engineered PGPR to over express one or more of these traits so that strains with several different anti-pathogen traits can act synergistically (Glick and Bashan, 1997 and Niranjan et al 2005).
Among PGPR, fluorescent pseudomonads occur commonly in the rhizosphere of plants and they have immense potential in agriculture for use as biofertilizer, biocontrol agent and in bioremediation due to their plant growth-promoting ability, antagonistic activity and degradation of pollutants (Sasirekha et al 2012). The development of biological techniques using PGPR amended with suitable bioformulations is an emerging trend in plant protection to reduce the plant diseases caused by plant pathogens. Production of antibiotics, siderophore, HCN by $P$. fluorescens against fungal pathogens were reported by many workers (Bharathi et al 2004, Vivekananthan et al 2004 and Sendhilvel et al 2005). Plant association with PGPR may affect the structure and species composition of the bacterial community that colonizes plant tissues. Also, prevent pathogens to correlate with plant roots (Montesinos et al 2002 and Kuklinsky-Sobral et al 2004).

Concerning the chemical fertilization treatments, data presented in Table (2) showed that using of chemical fertilizer gave higher infection percentage compared to biofertilization treatment. This result confirmed the importance of biofertilization not only as a fertilizer but also as plant protection agents. These results are in harmony with those obtained by Abdelrahman (2009).

Response of cowpea plantlets to infection by $F$. oxysporum (Table 2) showed the disease severity score of cowpea varieties 45 days after the inoculation. Data revealed that disease severity of wilting of cowpea plants was the highest in case of untreated soil (control). Whereas, the lowest percentage was observed in the treatment of fungicide application. These results are in agreement with Zaghloul et al (2007).

In all infected treatments, disease severity in non-inoculated plants were significantly higher than those of inoculated plants. In spite of the fact that the treatment of the infected plants with the fungicide significantly lowered disease severity, treatment with either $P$. fluorescens or with the fungicide significantly reduced disease severity of the inoculation with the pathogen.

In this connection, significantly decrease in disease severity was achieved in the treatment which treated with biofertilization in the prescence of $P$. fluorescens when applied with the half dose of chemical $\mathrm{N}$.

Except the fungicide treatment, data in Table (2) showed that inoculation with Bradyrhizobium sp. in combination with $B$. circulans, $B$. megaterium and Glomus macrocarpum in the prescence of $P$. 
fluorescens significantly decreased the disease severity of wilting diseases of cowpea plants compared to other treatments. This result could be attributed to the synergistic effect in case of dual inoculation. These results are in harmony with those reported by Cal et al (2004) and Zaghloul et al (2007) who found that the combination of $A$. chroococcum and biocontrol agents significantly decreased disease severity in comparison with the individual ones. The mechanism of $P$. fluorescens and Bacillus on pathogens is by attacking and binding to the pathogenic organisms by sugar linkage and begins to secrete extracellular protease and / or lipase.

Dual inoculation with half dose of chemical nitrogen fertilizer $+P$. fluorescens showed lower percentage of disease severity than either the application each of full dose of chemical nitrogen fertilization or biofertilization + half dose of chemical nitrogen fertilization.

The disease severity by biocontrol agents is regarded sustainable via harmonization of interactions among plants, pathogens, biocontrol agents and microbial communities within rhizosphere (Whipps, 2001 and Gao et al 2012). Many reports found that inoculation with rhizobia and/or arbuscular mycorrhizal fungi (AMF) could promote plant growth and control fungal diseases, and thus be considered as one of the efficient biocontrol approaches (Chandanie et al 2006 and Pozo and Azcon-Aguilar, 2007).

The obtained results indicated that, inoculation with mixed biofertilizers in prescence of AM significantly reduced the percentage of disease severity in infected cowpea plants. These findings are in agreement with that of Chandanie et al (2006) who found that, pre-inoculation with AM fungi led to a significant reduction in disease severity caused by $R$. solani in economically important crops (mung bean, potato, and cucumber). Plants might have evolved different strategies to defend themselves against pathogens. Systemic acquired resistance (SAR) plays an important role in the ability of plants to defend themselves against pathogens. SAR occurs in all or most plants in response to colonization of AM fungi (AbdelFattah et al 2011).

Effect of biofertilization and biological control on some soil enzymes activity and AM infection percentage

The general biochemical properties of soil such as, dehydrogenase activity (DHA) was estimated as a guide of respiration rate and total microbial activity in soil. Whereas, nitrogenase activity $\left(\mathrm{N}_{2}{ }^{-}\right.$ ase) was determined in root nodules as an indicator to $\mathrm{N}_{2}$-fixation activity. These are the general indicators of soil quality related to the biocycling of elements such as C, N, P and S (Gil-Sotresa et al 2005). On the other hand, alkaline phosphatase activity was determined in soil as a guide of organic phosphorus compounds degradation.

Dehydrogenase is an intracellular enzyme related to the oxidative phosphorylation process (Pathma and Sakthivel, 2012) and is an indicator of microbial activity in soil and other biological ecosystems (Garcia et al 1997).

The obtained results in Table (3) indicated that sterilized soil treatments appeared lower values of DHA rather than non-sterilized ones which gave higher values of DHA, that could be attributed to the presence of native (indigenous) soil microorganisms besides the introduced inocula in nonsterilized soil treatments. This result is likely be due to the sterilization effect, since the sterilization lead to getting rid of native soil microorganisms. These results are in harmony with those obtained by Abdelrahman (2009).

Dehydrogenase activity which was observed with sterilized treatments may be due to the activity of introduced inocula only. Biofertilizer strains combined with soil infestation with F. oxysporum in presence of $P$. fluorescens gave higher values of DHA compared to individual treatments.

Similar trend of results was observed with sterilized and non-sterilized soil treatments. It was also revealed that infested soil with $F$. oxysporum significantly increased DHA. This may attributed to the effect of $F$. oxysporum mycelium in increasing the total microbial biomass. So, it is worthily to mention that cowpea inoculation with biofertilizer strains significantly increased DHA compared to the uninoculated one.

Generally, higher values of DHA which was observed in dual application with biofertilizers and biocontrol agent interpret the beneficial effect of inoculation in proliferation and enhancement of microbial biomass in rhizosphere.

The highest record of DHA in non-sterilized soil treatments was observed with biofertilizers inoculation combined with soil infestation with $F$. oxysporum in presence of Ps. fluorescens. While, the lowest DHA record was observed with the infested and sterilized soil. $\mathrm{N}_{2}$-ase activity was periodically determined as an indication of $\mathrm{N}_{2}$-fixers. Also, was determined in soil as a criterion of atmospheric nitrogen fixation by diazotrophs. 

diseases controlling under greenhouse conditions

Table 3. Effect of biofertilization and /or chemical fertilization combined with $P$. fluorescens on some soil enzymes activity and AM infection percentage.

\begin{tabular}{|c|c|c|c|c|c|c|c|c|}
\hline & \multicolumn{4}{|c|}{ Non - sterlilized soil } & \multicolumn{4}{|c|}{ Sterilized soil } \\
\hline & $\begin{array}{c}\text { Dehy- } \\
\text { drognase } \\
\mu \mathrm{g} \text { TPF/g } \\
\text { dry soil/day }\end{array}$ & $\begin{array}{c}\text { Nitrogenase } \\
\text { activity as } \\
\mu \mathrm{l} \mathrm{C2H} 4 / g \text { dry } \\
\text { nodules/h }\end{array}$ & $\begin{array}{c}\text { Phosphatase } \\
\text { activity } \\
\text { as } \mu \mathrm{g} \mathrm{P/g} \mathrm{dry} \\
\text { soil/day }\end{array}$ & $\begin{array}{c}\text { AM coloni- } \\
\text { zation } \\
\%\end{array}$ & $\begin{array}{c}\text { Dehy- } \\
\text { drognase } \\
\mu \mathrm{g} \text { TPF/g dry } \\
\text { soil/day }\end{array}$ & $\begin{array}{c}\text { Nitrogenase } \\
\text { activity as } \\
\mu \mathrm{l} \mathrm{C} 2 \mathrm{H} 4 / \mathrm{g} \text { dry } \\
\text { nodules/h }\end{array}$ & $\begin{array}{c}\text { Phosphatase } \\
\text { activity } \\
\text { as } \mu \mathrm{g} \mathrm{P} / \mathrm{g} \text { dry } \\
\text { soil/day }\end{array}$ & $\begin{array}{l}\text { AM colo- } \\
\text { nization \% }\end{array}$ \\
\hline \multicolumn{9}{|c|}{ Without F. oxysporum } \\
\hline T1 & $16.75^{\mathrm{k}}$ & $19.00^{p}$ & $15.16^{j}$ & 7.33 & $6.66^{n}$ & $0.00^{r}$ & $9.30^{\mathrm{m}}$ & 0.00 \\
\hline T2 & $21.17^{j}$ & $33.73^{n}$ & $17.63^{\mathrm{i}}$ & 11.00 & $9.00^{\mathrm{m}}$ & $0.00^{r}$ & $13.21^{k}$ & 0.00 \\
\hline T3 & $40.20^{d}$ & $42.66^{1}$ & $18.96^{\mathrm{h}}$ & 0.00 & $20.86^{j}$ & $41.96^{\prime}$ & $15.06^{j}$ & 0.00 \\
\hline T4 & $38.06^{\mathrm{e}}$ & $82.76^{\mathrm{g}}$ & $24.81^{d}$ & 74.00 & $24.83^{\mathrm{h}}$ & $62.26^{\mathrm{k}}$ & $21.31^{g}$ & 61 \\
\hline T5 & $53.93^{\mathrm{a}}$ & $232.01^{\mathrm{a}}$ & $33.50^{\mathrm{a}}$ & 81.00 & $28.36^{9}$ & $116.00^{d}$ & $24.80^{d}$ & 71.66 \\
\hline T6 & $50.56^{\mathrm{b}}$ & $105.03^{e}$ & $27.53^{\mathrm{C}}$ & 18.33 & $25.20^{\mathrm{h}}$ & $76.10^{\mathrm{h}}$ & $24.06^{\mathrm{de}}$ & 0.00 \\
\hline \multicolumn{9}{|c|}{ With F. oxysporum } \\
\hline T1 & $15.42^{l}$ & $13.46^{q}$ & $12.33^{\mathrm{kl}}$ & 5.00 & $8.33^{\mathrm{m}}$ & $0.00^{r}$ & $7.46^{n}$ & 0.00 \\
\hline T2 & $22.36^{i}$ & $21.76^{\circ}$ & $15.06^{j}$ & 7.00 & $15.96^{\mathrm{kl}}$ & $0.00^{r}$ & $12.21^{\prime}$ & 0.00 \\
\hline T3 & $22.46^{i}$ & $19.60^{p}$ & $17.43^{\mathrm{i}}$ & $0.00^{\prime}$ & $28.83^{9}$ & $37.21^{\mathrm{m}}$ & $14.56^{\mathrm{j}}$ & 0.00 \\
\hline T4 & $47.86^{\mathrm{C}}$ & $76.43^{i}$ & $24.30^{\text {de }}$ & 64.66 & $24.90^{\mathrm{h}}$ & $42.30^{\prime}$ & $17.03^{i}$ & 51.00 \\
\hline T5 & $55.00^{\mathrm{a}}$ & $213.2^{b}$ & $30.16^{b}$ & 75.00 & $38.23^{\mathrm{e}}$ & $119.36^{c}$ & $23.53^{\mathrm{e}}$ & 64.00 \\
\hline T6 & $53.83^{\mathrm{a}}$ & $68.53^{f}$ & $27.00^{\mathrm{C}}$ & 15.00 & $36.00^{f}$ & $65.26^{j}$ & $22.33^{\dagger}$ & 0.00 \\
\hline
\end{tabular}

For more details about T1-T6 see Fig 1.

Data presented in Table (3) also showed that non-sterilized soil treatments gave higher values of $\mathrm{N}_{2}$-ase rather than sterilized soil. This result may be attributed to the sterilization effect. The $\mathrm{N}_{2}$-ase activity which was observed with sterilized treatments is likely be due to the activity of introduced biofertilizers inocula. This result is likely be due to the activity of native microorganisms in nonsterilized soil treatments beside the introduced inocula.

It is noticeable that soil infestation with $F$. oxysporum showed lower values of $\mathrm{N}_{2}$-ase activity in both non-sterilized and sterilized soil than uninfested ones. The lower value of $\mathrm{N}_{2}$-ase activity which was observed with soil infested by pathogenic fungus may be due to the antagonistic effect of such fungus against $\mathrm{N}_{2}$ - fixers (Abdelrahman, 2009).

Also data indicated that the highest nitrogenase activity was observed in inoculated cowpea with the biofertilizers rather than chemical fertilization. These results are in harmony with those obtained by Holl et al (1988) who reported that inoculation showed high nitrogenase activity. Increase dose of nitrogen fertilizer led to marked decrease in nodulation of cowpea and amount of $\mathrm{N}_{2}$-fixed (Hassan et al 1990).

Zaghloul (1999) and Shalaby (2001) reported that the highest values, of nitrogenase activity in rhizosphere was obtained with inoculated treat- ments with $\mathrm{N}_{2}$-fixers compared to un-inoculated ones.

The present study mentioned that inoculation with $P$. fluorescens showed a significant increase in $\mathrm{N}_{2}$-ase activity in all treatments in either nonsterilized or sterilized soil compared to uninoculated ones. Also dual application with biofertilizers and $P$. fluorescens gave higher records of $\mathrm{N}_{2}$-ase activity compared to biofertilizers inoculation singly. This may be attributed to the synergistic effect between all PGPR used.

Generally, the highest record of $\mathrm{N}_{2}$-ase activity was observed with non-sterilized and infested soil treated with both biofertilizers and $P$. fluorescens. While, the lowest record was observed in infested soil with $F$. oxysporum individually.

Concerning phosphatase activity, data presented in Table (3) emphasized that sterilized soil treatments gave lower values of phosphatase activity compared to un- sterilized ones. This result is logic and could be attributed to the sterilization effect as mentioned before with DHA and $\mathrm{N}_{2}$-ase activity.

Soil phosphatases play a major role in the mineralization P- ase processes of organic phosphorus substrates. Enzymes in soils originate from animal, plant and microbial sources and the resulting soil biological activity. The activity of soil phosphatases can be influenced by numerous factors and soil properties and farming systems play a key 
role among them. Phosphatase has the potential to directly and indirectly influence phosphorus transformation by participating in chemical reaction and influencing microbial processes that drive $P$ solubilization (Bunemann et al 2004).

The obtained results also emphasized that cowpea inoculation with the biofertilizer strains gave significant increase of phosphatase activity compared with chemical fertilization. This result is in agreement with Kuklinsky -Sobral et al (2004) who found that during initial colonization with phosphate solubilizing bacteria led to increase in phosphate availability and phosphatase activity.

In another view, inoculation with biofertilizer strains gave a significant increase in phosphatase activity. This was true with sterilized and nonsterilized soil treatments. Moreover, higher values of phosphatase activity which was observed in case of biofertilization could be attributed to proliferation of rhizosphere soil microorganisms and consequently increased phosphatase activity. Ponmurgan and Gopi (2006) and Abou-Aly et al (2006) reported that there is a positive correlation between phosphate solubilizing bacteria and phosphatase activity. Also, they reported that dual inoculation especially with Bacillus megaterium and mycorrhiza gave maximum values of phosphatase activity.

Inoculation of cowpea with $P$. fluorescens gave higher records of phosphatase activity than uninoculated ones. These results were observed in non-sterilized and sterilized soil.

In addition, results clearly indicated that cowpea inoculation with biofertilizers in presence of $F$. oxysporum increased the phosphatase activity compared to soil infested with $F$. oxysporum only. Generally, soil infestation with $F$. oxysporum decreased phosphatase activity in all treatments compared with non-infested ones. This may be likely due to antagonistic effect between indigenous soil fungi besides the introduced inocula and pathogenic fungus This result is in agreement with (Zaghloul et al 2008 and Abdelrahman, 2009).

Data in Table (3) showed the effect of chemical nitrogen fertilization, biofertilization, and biological control on mycorrhizal percentage in sterilized and non-sterilized soil. The lowest mycorrhizal colonization observed in uninoculated plants indicated that soil contains some mycorrhizal propagules. The AM percentage of colonization significantly increased with $\mathrm{AM}$ inoculation and increased with nitrogen application and then declined (Elsammani and Ahmed, 1998).
In addition, obtained data in Table (3) revealed that the rhizosphere of cowpea plants treated with full dose of chemical nitrogen fertilization in combination with fungicide don't emphasized any records of mycorrhizal root infection as compared to chemical nitrogen fertilization amendment individually.

Moreover, mycorrhizal root colonization percentage, was higher in case of biofertilization inoculated combined with half dose of nitrogen treatments in comparison with either chemical nitrogen fertilization combined with fungicides or chemical nitrogen fertilization (full dose) amendment only. Low percentage of mycorrhizal colonization in the un-inoculated plants depended on the indigenous AM in the soil and indicated that the native AM fungi are presented in the soil but with low density. These results are in harmony with those reported by Mikhaeel et al (2000).

Inoculation of cowpea plants with AM fungi markedly increased the percentage of mycorrhizal colonization. On the other hand, Pseudomonas had slightly effect on mycorrhizal colonization than inoculated with biofertilizers alone. These results could be due to the high microbial activity in rhizosphere of mycorrhizal plants and on rhizoplane limits, the root exudates recovered from roots and subsequent competition between bacteria and AM fungi for those sources. On the other hand, percentage of mycorrhizal colonization were present at low densities in the rhizosphere of cowpea plants grown in control treatments of each amended with full NPK. These attributed to some indications that soil microbes might be involved in the inhibition of spore germination and root colonization in non-sterilized soil (Abdel Karem et al 2000).

\section{Effect of biofertilization and biological control on growth characteristics of cowpea}

Data in Table (4) showed that the lower records of cowpea plants growth characteristics, i.e., plant height, number of branches/plants, number of leaves/plants, plant fresh weight and plant dry weight were observed in plants treated with chemical fertilizers only than plants treated with biofertilizers. This result agrees with Lisette et al (2003) who proved that co-inoculation with rhizobia and AM fungi could dramatically enhance pea growth. In general, all growth parameters were significantly reduced in cowpea plants infected with $F$. oxysporum when compared to the uninfected ones. 
However, mycorrhizal colonization significantly enhanced the growth parameters of the infected cowpea plants.

All tested parameters were significantly achieved after inoculation with AM fungi. This result is in agreement with (Abdel-Fattah et al 2011). At the same time, treatment of both infected and uninfected plants with fungicide led to a significantly increase in growth parameters. Fungicide had higher stimulation effect on cowpea plant growth characters than control. Also, data clearly indicated the highest records of all estimated parameters were observed in plants inoculated with biofertilizers in combination with chemical fertilization. Moreover, the results revealed that the com- bined inoculation of Bradyrhizobium sp., Bacillus megaterium, Bacillus circulans and Glomus macrocarpum with $P$. fluorescens and chemical fertilization significantly increased the plant height at 60 days under non-infested and infested soil with $F$. oxysporum. Attia and Hamed (2005) showed that combined inoculation with Bradyrhizobium, $B$. megaterium gave increased plant height and dry weight. This result is in agreement with Nour and Tolba (2015) who reported that bio-inoculation cowpea plants with the tested strains induced stimulative effect on vegetative growth parameters compared to control treatmentse obtained by ElMohamedy et al (2015).

Table 4. Effect of biofertilization and biological control on growth characteristics of cowpea at 60 days (flowering stage).

\begin{tabular}{|c|c|c|c|c|c|c|c|c|c|c|}
\hline & \multicolumn{5}{|c|}{ Non - sterilized soil } & \multicolumn{5}{|c|}{ Sterilized soil } \\
\hline & $\begin{array}{l}\text { Plant } \\
\text { height } \\
(\mathrm{cm})\end{array}$ & $\begin{array}{c}\text { Number } \\
\text { of } \\
\text { branches }\end{array}$ & $\begin{array}{c}\text { Number } \\
\text { of } \\
\text { leaves }\end{array}$ & $\begin{array}{l}\text { Fresh } \\
\text { weight } \\
\text { (g)/plant }\end{array}$ & $\begin{array}{c}\text { Dry weight } \\
\text { (g)/ plant }\end{array}$ & $\begin{array}{c}\text { Plant height } \\
(\mathrm{cm})\end{array}$ & $\begin{array}{c}\text { Number } \\
\text { of } \\
\text { branches }\end{array}$ & $\begin{array}{l}\text { Number } \\
\text { of leaves }\end{array}$ & $\begin{array}{c}\text { Fresh } \\
\text { weight } \\
\text { (g)/plant }\end{array}$ & $\begin{array}{c}\text { Dry weight } \\
\text { (g)/plant }\end{array}$ \\
\hline \multicolumn{11}{|c|}{ Without $F$. oxysporum } \\
\hline T1 & $46.13^{g}$ & $5.36^{\dagger}$ & $14^{\mathrm{h}}$ & $42.76^{i}$ & $12.12^{\mathrm{e}}$ & $36.3^{n}$ & $3.56^{\mathrm{h}}$ & $9^{j}$ & $28.66^{\circ}$ & $10.22^{g}$ \\
\hline $\mathrm{T} 2$ & $48.03^{\mathrm{e}}$ & $6.43^{\mathrm{de}}$ & $21^{\text {cde }}$ & $50.83^{\mathrm{e}}$ & $13.12^{d}$ & $39.9^{1}$ & $4.4^{\mathrm{g}}$ & $17^{9}$ & $36.56^{1}$ & $11.15^{f}$ \\
\hline Т3 & $50.03^{d}$ & $7.06^{\mathrm{bc}}$ & $25^{\mathrm{b}}$ & $54.7^{\mathrm{d}}$ & $13.36^{d}$ & $42.81^{\mathrm{ij}}$ & $5.43^{f}$ & $21^{\text {cde }}$ & $39.7^{\mathrm{k}}$ & $12^{\mathrm{e}}$ \\
\hline $\mathrm{T} 4$ & $51.23^{\mathrm{c}}$ & $7.5^{\mathrm{b}}$ & $25.66^{b}$ & $60.8^{\mathrm{b}}$ & $14.08^{\mathrm{c}}$ & $43.83^{h}$ & $5.46^{\dagger}$ & $22^{\mathrm{cd}}$ & $42.86^{i}$ & $12.26^{\mathrm{e}}$ \\
\hline T5 & $55.93^{\mathrm{a}}$ & $8.4^{\mathrm{a}}$ & $27.66^{\mathrm{a}}$ & $65.8^{\mathrm{a}}$ & $17.07^{\mathrm{a}}$ & $76.73^{f}$ & $6.86^{\mathrm{cd}}$ & $25^{\mathrm{b}}$ & $47.9^{f}$ & $15.22^{b}$ \\
\hline T6 & $53.23^{b}$ & $7.16^{\mathrm{bc}}$ & $25^{\mathrm{b}}$ & $61.83^{\mathrm{b}}$ & $15.19^{b}$ & $43.83^{h}$ & $5.96^{\mathrm{e}}$ & $22^{\mathrm{cd}}$ & $43.33^{i}$ & $13.33^{d}$ \\
\hline \multicolumn{11}{|c|}{ With F. oxysporum } \\
\hline $\mathrm{T} 1$ & $36.23^{n}$ & $3.46^{\mathrm{h}}$ & $11^{i}$ & $33.23^{n}$ & $10.08^{g}$ & $0^{r}$ & $0^{i}$ & $0^{k}$ & $0^{9}$ & $0^{i}$ \\
\hline $\mathrm{T} 2$ & $38.73^{\mathrm{m}}$ & $4.4^{\mathrm{g}}$ & $18^{\mathrm{fg}}$ & $40.73^{\mathrm{j}}$ & $11.07^{\dagger}$ & $32.26^{q}$ & $3.36^{\mathrm{h}}$ & $12.66^{\mathrm{h}}$ & $27.43^{\mathrm{p}}$ & $9.33^{h}$ \\
\hline T3 & $41.16^{\mathrm{k}}$ & $5.13^{f}$ & $20.66^{\text {de }}$ & $44.86^{h}$ & $11.42^{f}$ & $33.1^{p}$ & $4.3^{\mathrm{g}}$ & $17^{9}$ & $35.23^{m}$ & $10.42^{g}$ \\
\hline T4 & $42.23^{j}$ & $5.43^{f}$ & $22^{\mathrm{cd}}$ & $50.6^{\mathrm{e}}$ & $12.05^{\mathrm{e}}$ & $33.96^{\circ}$ & $4.16^{g}$ & $19.66^{\text {ef }}$ & $39.73^{\mathrm{k}}$ & $10.29^{g}$ \\
\hline T5 & $46.06^{g}$ & $7.53^{b}$ & $25^{b}$ & $56.2^{c}$ & $14.22^{c}$ & $35.8^{n}$ & $6.2^{\mathrm{e}}$ & $22.66^{\mathrm{C}}$ & $46.33^{g}$ & $13.19^{d}$ \\
\hline T6 & $43.3^{\mathrm{hi}}$ & $6.1^{\mathrm{e}}$ & $21.66^{\mathrm{cd}}$ & $54.03^{d}$ & $13.05^{d}$ & $33.03^{p}$ & $5.13^{f}$ & $19.66^{\text {ef }}$ & $41.43^{j}$ & $11.3^{f}$ \\
\hline
\end{tabular}

For more details about T1-T6 see Fig 1.

The higher growth characters which observed with PGPR inoculation could be attributed to the beneficial effects include cell division, cell enlargement, root initiation, shoot growth increase, development and formation of flowers and translocation of nutrients and organic substances (Leveau and Lindow, 2005 and Pallai, 2005). Also, PGPR strain mixtures induce systemic resistance against diseases of several different plant hosts (Kanchalee and Joseph, 2002). PGPR can suppress diseases through antagonism between bacteria and soil-borne pathogens, as well as by in- ducing a systemic resistance in the plant against both root and foliar pathogens. The induced resistance constitutes an increase in the level of basal resistance to several pathogens simultaneously, which is of benefit under natural conditions where multiple pathogens exist (Van Loon and Glick, 2004 and Devendra and Bhavdish, 2009).

Also, Many reports found that inoculation with arbuscular mycorrhizal fungi (AMF) could promote plant growth and control fungal diseases, and thus be considered as one of the efficient biocontrol approaches (Chandanie et al $\mathbf{2 0 0 6}$ and Pozo and 
Azcon, 2007). AMF inoculation not only helped host plant growth, but also enhanced defense system and subsequently reduced disease severity on many soil-borne pathogens (Xiang et al 2012).

The obtained results are come to the same conclusion with Askar and Rashad (2010) who found that the uptake of other essential micronutrients from the soil by the AM fungal hyphae might also play a role in general plant growth improvement as well as in more indirect effects upon the $\mathrm{N}_{2}$-fixing system. Also, El-Shenawy and Fayed (2005) reported that the use of silicate dissolving bacteria (Bacillus circulans) are generally used to release potassium from rock-feldspar thus, potassium application was effective for enhanced vegetative growth.

Data in Table (4) showed that soil infestation with $F$. oxysporum significantly decreased the growth characteristics compared to un-infested ones. The highest record of cowpea growth characteristics was observed in non-sterilized soil which was inoculated with biofertilizers in presence of $P$. fluorescens.

Different modes of action for Psedomonas sp. have been reported, including the production of different antimicrobial compounds (Tharne et al 2000 and Nandi et al 2013), competition and induction of plant defense mechanisms (Tonelli et al 2011 and Nandi et al 2013). Recent investigation on mechanisms of biological control by plant growth promoting rhizobacteria (PGPR) like fluorescent pseudomonads revealed that PGPR strains protects plants from pathogen attack by strengthening the epidermal and cortical walls with deposition of newly formed barriers beyond infection sites (Nandi et al 2013).

There were significant beneficial interactions between the chemical fertilizers and microbial inoculations for plant height, number of branches and leaves as well as for both fresh and dry weights/plant, when compared to the control (untreated plants). These results are in agreements with Abdel-Aziz and Salem (2013). Similar results were also reported by Kahlon and Sharanappa (2006) who found that a phosphorus-solubilizing bacterium (Bacillus megaterium) and arbuscular mycorrhiza (Glomus mosseae) resulted in higher dry matter accumulation in leaves, stem and total dry matter accumulation.

Effect of biofertilization and biological control on total phenol, peroxidase and polyphenol oxidase activity.

Data in Table (5) clearly indicated that soil infestation with $F$. oxysporum significantly increased the total phenol, peroxidase and polyphenol oxidase activity in cowpea compared with un-infested ones could be considered as an antioxidant mechanism for protecting plants against the effects of pectinase on the plant cell walls. Activities of oxidative enzymes in any infected plants tissues are known to contribute to disease resistance mechanisms through the oxidation of phenols Tarrad et al (1993) and Yehia et al (2004). This result could be attributed to those enzymes responsible for resistance against plant root infection.

Mandal et al (2009) mentioned that peroxidases (PO) and polyphenol oxidase (PPO) are important in the defense mechanism against pathogens, through their role in the oxidation of phenolic compounds to quinines, causing increasing in antimicrobial activity. Therefore, they may be directly involved in stopping pathogen development (Abdel-Aziz and Salem, 2013). Increasing the peroxidase and polyphenol oxidase activity in the PGPR treated plants may play either a direct or indirect role in the suppression of pathogen development in the host (Chen et al 1998 and Diby et al 2001). Induction of defense responses by plant growth promoting rhizobacteria (PGPR) is largely associated with the production of oxidative enzymes like phenolic compound, (PO) and (PPO) (Nandi et al 2013).

Phenolic compounds may be fungitoxic in nature and may increase the mechanical strength of the host cell wall. The hyphae of the pathogen surrounded by phenolics substances exhibited considerable morphological changes including cytoplasmic disorganization and loss of protoplasmic content. The present study shows higher accumulation of phenolics in cowpea and there after a rapid degradation. 
Table 5. Effect of biofertilization and biological control on total phenol, peroxidase and polyphenol oxidase activity.

\begin{tabular}{|c|c|c|c|c|c|c|}
\hline & \multicolumn{3}{|c|}{ Non - sterlilized soil } & \multicolumn{3}{|c|}{ Sterilized soil } \\
\hline & $\begin{array}{c}\text { Total phe- } \\
\text { nol } \\
(\mu \mathrm{Mol} / \mathrm{g} \\
\mathrm{LFW})\end{array}$ & $\begin{array}{c}\text { Peroxidase } \\
\text { ( } \mu \text { Mol/g } \\
\text { LFW })\end{array}$ & $\begin{array}{c}\text { Polyphenol } \\
\text { oxidase } \\
\text { ( } \mu \mathrm{Mol} / \mathrm{g} \text { LFW) }\end{array}$ & $\begin{array}{c}\text { Total phenol } \\
(\mu \mathrm{Mol} / \mathrm{g} \text { LFW })\end{array}$ & $\begin{array}{c}\text { Peroxidase } \\
(\mu \mathrm{Mol} / \mathrm{g} \text { LFW })\end{array}$ & $\begin{array}{c}\text { Polyphenol } \\
\text { oxidase } \\
(\mu \mathrm{Mol} / \mathrm{g} \text { LFW) }\end{array}$ \\
\hline \multicolumn{7}{|c|}{ Without F. oxysporum } \\
\hline T1 & $1.19^{n}$ & $5.36^{\mathrm{mn}}$ & $5.4^{\mathrm{k}}$ & $0.99^{n}$ & $5^{n}$ & $5.13^{k}$ \\
\hline T2 & $1.75^{\mathrm{Im}}$ & $5.56^{\mathrm{Im}}$ & $6.6^{\mathrm{hi}}$ & $2^{1}$ & $5.83^{\mathrm{klm}}$ & $7.46^{\mathrm{fg}}$ \\
\hline T3 & $2.36^{k}$ & $5.96^{\mathrm{kl}}$ & $6.46^{\mathrm{ij}}$ & $2.55^{\mathrm{k}}$ & $6.56^{\mathrm{hi}}$ & $7.56^{\mathrm{fg}}$ \\
\hline T4 & $2.66^{\mathrm{jk}}$ & $6.53^{\text {hij }}$ & $7.5^{\mathrm{fg}}$ & $3.3^{\mathrm{gh}}$ & $7.46^{\text {ef }}$ & $7.76^{\text {ef }}$ \\
\hline T5 & $4.54^{d}$ & $9.16^{c}$ & $8.56^{\mathrm{cd}}$ & $4.88^{c}$ & $10.26^{\mathrm{b}}$ & $9.3^{\mathrm{ab}}$ \\
\hline T6 & $3.12^{\mathrm{hi}}$ & $6.9^{g h}$ & $7.5^{\mathrm{fg}}$ & $3.67^{f}$ & $7.86^{\mathrm{de}}$ & $8.16^{\mathrm{de}}$ \\
\hline \multicolumn{7}{|c|}{ With F. oxysporum } \\
\hline T1 & $1.64^{\mathrm{m}}$ & $6.2^{\mathrm{ijk}}$ & $5.93^{j}$ & $0^{\circ}$ & $0^{\circ}$ & $0^{\prime}$ \\
\hline T2 & $2.02^{1}$ & $6.03^{\mathrm{jkl}}$ & $6.36^{\mathrm{ij}}$ & $2.43^{k}$ & $6.5^{\mathrm{hij}}$ & $7.06^{\text {gh }}$ \\
\hline T3 & $2.69^{\mathrm{jk}}$ & $6.53^{\mathrm{hij}}$ & $7.13^{g h}$ & $2.94^{\mathrm{ij}}$ & $6.76^{\mathrm{gh}}$ & $7.9^{\text {ef }}$ \\
\hline $\mathrm{T} 4$ & $3.32^{\mathrm{gh}}$ & $7.1^{\text {fg }}$ & $7.83^{\text {ef }}$ & $3.86^{\text {ef }}$ & $7.96^{\mathrm{de}}$ & $8.06^{\text {def }}$ \\
\hline T5 & $5.57^{\mathrm{b}}$ & $10.13^{b}$ & $9.03^{b c}$ & $5.9^{\mathrm{a}}$ & $10.86^{\mathrm{a}}$ & $9.67^{a}$ \\
\hline T6 & $3.55^{\mathrm{fg}}$ & $7.5^{\text {ef }}$ & $8^{\text {def }}$ & $4.15^{\mathrm{e}}$ & $8.2^{\mathrm{d}}$ & $8.53^{\mathrm{cd}}$ \\
\hline
\end{tabular}

For more details about T1-T6 see Fig 1.

In many instances, phenols serve as plant defense mechanisms against predation by insects, herbivores and microorganisms (Beckman, 2000). Phenolics that occur constitutively and function as preformed inhibitors are generally referred to as phytoanticipins, and those that are produced in response to infection by the pathogen are called phytoalexins and constitute an active defense response.

In the present study, a higher accumulation of phenolics was recorded in cowpea plants inoculated with pathogens compared to other treatments. This increase in phenol content might indicate a possible involvement of such compounds in the enhanced resistance of cowpea plants to pathogen F. oxysporum by PGPR. This might have contributed to reduce infection by the $F$. oxysporum in cowpea plants. Furthermore, peroxidase is involved in the production or modulation of active oxygen species which may play various roles directly or indirectly in reducing pathogen viability and spread (Lamb and Dixon, 1997 and Nandi et al 2013). Similarly, the higher PO activity was noticed in cucumber roots treated with Pseudomonas (Chen et al 2000). Biochemical analysis of plants raised from seeds treated with $P$. fluorescens showed an early induction of PO (Nandakumar et al 2001).

Mohamed et al (2012) found an increases in the enzymes activities of PO and PPO in PGPR treated cowpea compared with the infested soil without any treatment. The PPO activity was increased in cowpea plants inoculated with pathogen after inoculation. Similarly, induction of defense responses by PGPR is associated with the production of oxidative enzymes like PPO reported by Nandi et al (2013). PO and PPO play a central role triggering the hypersensitive reaction (HR), in cross linking and lignifications of the cell wall and in transducing signals to adjacent non-challenged cells (Lamb and Dixon, 1997).

Cowpea inoculated with $P$. fluorescens gave higher records of peroxidase and polyphenol oxidase. These results are in harmony with those stated by Meena et al (2000) who reported that phenolic compounds are known to play a major role in the defense mechanism of plants against various external infectious agents. Pseudomonas fluorescens releases antimicrobial factors including a lytic enzyme which leads to the accumulation of phenolics, by secretion of indole acetic acid that induced phenol metabolism in plants (Shabaev et al 1999).

Inoculation with biofertilizers resulted a significant increase in peroxidase and polyphenol oxidase activity of cowpea compared to un-inoculated ones. Similar results of elevated levels of peroxidase and polyphenol oxidase have been shown in plants treated with PGPR strains (Chen et al 2000). 
Generally, the biofertilization and chemical fertilization resulted a significant increase in total phenol, peroxidase and polyphenol oxidase activity in comparison treated with either biofertilization or chemical fertilization individually. This result showed the importance of biofertilizers not only to supply the nutritional needs of the plant but also to protect the plant against pathogens.

In addition, cowpea inoculation with biofertilizer strains combined with soil infestation with pathogenic fungus significantly increased the activity of peroxidase and polyphenol oxidase compared to soil infestation with pathogenic fungus alone.

Cowpea inoculation with $P$. fluorescens gave higher records of peroxidase and polyphenol oxidase rather than un-inoculated ones. These results are in harmony with those stated by Sahebani and Hadavi (2008) who reported that specific activities of resistance-related enzymes, namely peroxidase, polyphenol oxidase increased significantly in $P$. fluorescens inoculated plants.

\section{CONCLUSION AND RECOMMENDATION}

It can be concluded that the using of Bradyrhizobium sp., Bacillus megaterium, Bacillus circulans and Glomus macrocarpum with $P$. fluorescens are good factors of fertilization and bio-control management for cowpea production under Egyptian conditions. Moreover, they reduced the amount of NPK chemical fertilization, and therefore, limit the environmental pollution.

\section{REFERENCES}

Abdel-Aziz, M.A. and Salem, M.F. 2013. Effect of microbial inoculation on reduction cowpea (Vigna unguiculata, L. Walp) chemical fertilizers under newly reclaimed soils condition in Egypt. J. Plant Production, Mansoura Univ., 4 (5), 745 - 761.

Abdel-Fattah, G.M., El-Haddad, S.A., Hafez, E.E. and Rashad, Y.M. 2011. Induction of defense responses in common bean plants by arbuscular mycorrhizal fungi. Microbiological Research 166, 268-281.

Abdel-Hafez, A.M. 1966. Some studies on acid producing microorganisms in soil and rhizosphere with special reference to phosphate dissolvers. Ph.D. Thesis, Fac. Agric. Ain Shams Univ., Egypt, 31 p.

Abdel Karem, H., Radwan, S.M.A. and Attia, M. 2000. Impact of certain biofertilizers on cowpea plants in sludge amended sandy soil. Pakistan Journal of Biological Sciences 3(3), 423-428.

Abdelrahman, H.M. 2009. Bioorganic farming efficiency on yield and quality of some medicinal plants. Ph.D. Thesis, Botany Department, Faculty of Agriculture, Moshtohor, Benha University, Egypt.

Abou-Aly, H.E., Mady, M.A. and Moussa, S.A. M. 2006. Interaction effect between phosphate dissolving microorganisms and boron on squash (Cucurbita pepo L.) growth, endogenous phytohormones and fruit yield. J. Biol. Chem. Environ. Sci., 1(4), 751-774.

Ahmed G.A.B. 2010. Effect of bio-fertilization on growth and productivity of tomato. M.Sc. Thesis, Agric. Fac. Mansoura Univ., Egypt.

Akinbode, O. A. and Ikotun, T. 2008. Evaluation of some bioagents and botanicals in in vitro control of Colletotrichum destructivum. Afr. J. Biotechnol., 7(7), 868-872.

Al-Karaki, G.N. 2006. Nursery inoculation of tomato with arbuscular mycorrhizal fungi and subsequent performance under irrigation with saline water. Sci. Hortic., 109(1), 1-7.

Artursson, V., Finlay, R.D. and Jansson, J.K., (2006). Interactions between arbuscular mycorrhizal fungi and bacteria and their potential for stimulating plant growth. Environ. Microbiol., 8(1), 1-10.

Askar, A.A. and Rashad, Y.M. 2010. Arbuscular mycorrhizal fungi: a biocontrol agent against common bean Fusarium root rot disease. J. Plant Pathol., 9, 31-38.

Attia, M. and Hamed H.A. 2005. Induction of defense responses in tomato plants inoculated with phytostimulation microorganisms against Fusarium oxysporum. Arab. Univ. J. Agric. Sci. Ain Shams Univ., Cairo, 13, 689-705.

Beckman, C.H. 2000. Phenolic-storing cells: keys to programmed cell death and periderm formation in wilt disease resistance and in general defense responses in plants. Physiol. Mol. Plant Pathol., 57,101-110.

Bharathi, R., Vivekananthan, R., Harish, S., Ramanathan, A. and Samiyappan, R. 2004. Rhizobacteria based bioformulations for the management of fruit rot infection in chillies. Crop Protect, 23, 835-843.

Bunemann, E.K., Steinebrunner, F., Frossard, P.C., Oberson, A. 2004. Phosphorus dynamics in a highly weathered soil as revealed by isotopic labeling techniques. Soil Sci. Soc. Am. J., 68, 1645-1655. 
Impact of plant growth-promoting Rhizobacteria on cowpea growth performance and root diseases controlling under greenhouse conditions

Cal, A., Larena, I., Sabuquillo, P. and Melgarejo, P. 2004. Biological control of tomato wilts. Recent Research Developments in Crop Science, 1(1), 97-115.

Chandanie, W.A., Kubota, M. and Hyakumachi, M. 2006. Interactions between plant growth promoting fungi and arbuscular mycorrhizal fungus Glomus mosseae and induction of systemic resistance to anthracnose disease in cucumber. Plant Soil, 286, 209-217.

Chen, C., Belanger, R.R., Benhamou, N. and Paulitz, T.C. 1998. Induced systemic resistance by Pseudomonas spp impairs pre- and post- infection development of Pythium aphanidermatum on cucumber roots. Eur. J. Plant Pathol., 104, 877-886.

Chen, C., Belanger, R.R.V., Benhamou, N. and Paulitz, T. 2000. Defense enzymes induced in cucumber roots by treatment with plant growth promoting rhizobacteria (PGPR) and Pythium aphanidermatum. Physiological and Molecular Plant Pathology, 56, 13-23.

Devendra, K.C. and Bhavdish, N.J. 2009. Interactionsof Bacillus spp. and plants - With special reference to induced systemic resistance (ISR). Microbiological Research, 164, 493513.

Diby, P., Kumar, A., Anandaraj, M. and Sarma, Y.R. 2001. Studies on the suppressive action of fluorescent pseudomonads on Phytophthora capsici, the root rot pathogen of Black pepper. Indian Phytopathology, 54(4), 515-518.

Duncan's, D.B. 1955. Multiple range and multiple "F. test" Biometrics, 11, 1-42.

Eissa, N.H., Zayed, M.S. and Abdallah, M. 2015. Effect of Biofertilization and Soil Solarization on Pepper Quality, first ed. Lap Lambert Academic Publishing, 82 p.

El-Mohamedy, R.S.R., Shafeek, M.R., Shaheen, A.M., El-Samad, E.H., Rizk, A.A. and Morsey, A.A. 2015. Integration between Seed Bio Priming and Potassium Salts Treatments to Control of Root Rot Disease and Improvement Growth and Yield of Green Bean Plants. Current Science International, 4(2), 155-163.

Elsammani, A.A. and Ahmed, E.E. 1998. Effects of biological and chemical fertilizers on growth and symbiotic properties of faba bean under salt stress. U.K.J. Agric. Sci., 6(1), 150-164.

El-Shenawy, I.E. and Fayed, T.A. 2005. Evaluation of the conventional to organic and biofertilizers on (Crimson seedless) grape vines in comparison with chemical fertilizers. J. Agri. Cairo Univ., 20(1), 212-225.
Gao, X., Lu, X., Wu, M., Zhang, H., Pan, R., Tian, J., Shuxian and Li, H.L. 2012. Co-Inoculation with Rhizobia and AMF Inhibited Soybean Red Crown Rot: From Field Study to Plant DefenseRelated Gene Expression Analysis. PLoS ONE 7(3), 225-230.

Garcia, C. Hernandez, T. and Costa, F. 1997. Potential use of dehydrogenase activity as an index of microbial activity in degraded soils. Commun. Soil Sci. Plant Anal., 28,123-134.

Gerdemann, J.W. and. Nicolson, T.H. (1963). Spores of mycorrhizal endogenous species extracted from soil by wet sieving and decanting. Transactions of the British Mycological Society, 46, 234-244.

Gil-Sotresa, F., Trasar-Cepedab, C., Leirosa, M.C. and Seoane, S. 2005. "Different approaches to evaluating soil quality using biochemical properties", Soil Biol. Biochem., 37, 877-887.

Giri, B., Kapoor, R., Agarwal, L. and Mukerji, K., 2004. Preinoculation with arbuscular mycorrhizae helps Acacia auriculiformis grow in degraded Indian wasteland soil. Commun. Soil Sci. Plant Anal., 35(1-2), 193-204.

Glick, B. R. and Bashan, Y. 1997. Genetic manipulation of plant growth-promoting bacteria to enhance biocontrol of phytopathogens. Biotech. Advan., 15, 353-376.

Gupta, S., Arora, D.K. and Srivastava, A.K. 1995. Growth promoting of tomato plants by rhizobacteria and imposition of energy stress on Rhizoctonia solani. Soil Biol. Biochem., 27(8), 1051-1058.

Hassan, M. A. M.; Farrag, M. M. and Moharram, T. M. M. (1990). Response of cowpea to inoculation with Rhizobium and phosphorus fertilization rates. Minia J. Agric. Res. Dev., 12(2), 1045-1063.

Holl, F. B.; Chanwany, C. P.; Turkington, R. and Redley, R. A. (1988). Response of crested wheat grass (Agropyron cristatum L.), perennial ryegrass (Lolium perenne) and white clover (Trifolium repens L.) to inoculation with Bacillus polymyxa. Soil Biol. Biochem., 20(1), 19-24.

Hossam, H.M. and Zayed, M.S. 2015. Productivity of cowpea as affected by salt stress in presence of endomycorrhizae and Pseudomonas fluorescens. Annals of Agricultural Science, 60(2), 219-226.

Jacob, U. 2013. Assessing the need for inoculation of soybean and cowpea at tono in the Kassena Nankana district of the upper east region of Ghana. M.Sc. Thesis, Department of Crop 
and Soil Sciences, Faculty of Agriculture, Kwame Nkrumah University of Science and Technology, Ghana.

Janisiewicz, W.J., Tworkoski, T.J. and Sharer, C. 2000. Characterizing the mechanism of biological control of postharvest diseases on fruits with a simple method to study competition for nutrients. Phytopathology, 90(11), 1196-2000.

Kahlon, C.S. and Sharanappa, R.K. 2006. Dry matter accumulation and nodulation as influenced by phosphorus bioinoculants, zinc and sulfur in cowpea (Vigna unguiculata, L. Walp). Environment and Ecology., 1, 120-124.

Kanchalee, J. and Joseph, W.K. 2002. Mixtures of plant growth-promoting rhizobacteria for induction of systemic resistance against multiple plant diseases. Biological Control, 24, 285291.

Killani, A.S., Abaidoo, R.C., Akintokun, A.K. and Abiala, M.A. 2011. Antagonistic Effect of Indigenous Bacillus subtilis on Root-/Soil-borne Fungal Pathogens of Cowpea. Researcher, 3(3), 11-18.

King, E.O., Ward, M.K. and Ranney, D.E. 1954. Two simple media for the demonstration of pyocyanin and fluorescin. J. Lab. Clin. Med. 44, 301-307.

Kuklinsky-Sobral, J., Araujo, W.L., Mendes, R., Geraldi, I.O., Pizzirani-Kleiner, A.A. and Azevedo, J. L. 2004. Isolation and characterization of soybean-associated bacteria and their potential for plant growth promotion. Environ. Microbiol., 6(12), 1244-1251.

Lamb, C. and Dixon, R.A. 1997. The oxidative burst in plant disease resistance. Annu. Rev. Plant. Physiol. Plant. Mol Biol., 48, 251-275.

Landa, B.B., Hervas, A., Bethiol, W. and Jimenez-Diaz, R.M. 1997. Antagonistic activity of bacteria from the chickpea rhizosphere against Fusarium oxysporum f.sp.ciceris. Phytoparasitica 25, 305-318.

Leveau, J.H. and Lindow, S.E. 2005. Utilization of the plant hormone indole 3-acetic acid for growth by Pseudomonas putida strain 1290. Appl. Environ. Microbiol., 71(5), 2365-2371.

Linderman, R.G. 2000. Effects of mycorrhizas on plant tolerance to diseases. In: Kapulnik, Y., Douds (Jr), D.D., eds. Arbuscular mycorrizas physiology and function. Dordrecht, the Netherlands: Kluwer Academic Publishers, pp. 345 65.

Lisette, J., Xavier, C. and Germida, J.J. 2003. Selective interactions between arbuscular mycorrhizal fungi and Rhizobium leguminosarum bv. viciae enhance pea yield and nutrition. Biol. Fertil. Soil., 37, 261-267.

Loper, J.E. and Gross, H. 2007. Genomic analysis of antifungal metabolite production by Pseudomonas fluorescens Pf-5. Eur. J. Plant Pathol., 119, 265-278.

Mac Faddin, J.F. 1985. Media for isolation, cultivation, identification and maintenance of medical bacteria, vol.1. Williams \& Wilkins, Baltimore, MD, USA.

Mandal, S.; Mallick, N. and Mitra, A. 2009. Saliclic acid induced resistance to Fusarium oxysporum f.sp. lycopersici in tomato. Plant physiology and Biochemistry, 47, 642- 649.

Mayak, S., Tirosh, T. and Glick, B.R. 2004. Plant growth-promoting bacteria that confer resistance to water stress in tomatoes and peppers. Plant Sci., 166(2), 525-530.

Meena, B., Radhajeyalakshmi, R., Marimuthu, T., Vidhyasekaran, P., Sabitha, D. and Velazhahan, R. 2000. Induction of pathogenesis related proteins, phenolics and phenylalanine ammonia lyase in groundnut by Pseudomonas fluorescens. Zeitschrift fir Pflanzenkrantheiten and Pflanzeschutz, 107, 514-527.

Mikhaeel, F.T., Shalaby, A.M. and Mona, M.H. 2000. Dinitrogen fixation and nitrogen assimilation as influenced by dual (VA-mycorrhizal and Rhizobium) inoculation in soybean plants. Annals Agric Sci., Ain Shams Univ., Cairo, 45(I), 67-77.

Mohamed, G.M., Muhanna, N.A.S., Ragab, S.S.M. and Kamel, S.M.H. 2012. Evaluation of some environmentally safe chemicals and bioagents against Fusarium solani and Sclerotium rolfsii infected cowpea plants. J. Plant Prot. and Path., Mansoura Univ., 3(12), 12991319.

Montesinos, E., Banaterra, A., Badosa, E., Frances, J., Alemany, J., Liorente, I. and Moragega, C. 2002. Plant-microbe interactions and the new biotechnological methods of plant disease control. Intern. Microbiol., 5, 169-175.

Musandu, A.A.O. and Giller, K.E. 1994. Effect of vesicular-arbuscular mycorrhiza on kubzu (Pueraria phaseoloides) growth in phosphate fixing Kenya soils. African Crops Sci. J., 2(3), 285-290.

Nandakumar, R., Babu, S., Viswanathan, R., Raghuchander, T. and Swamiappan, $\mathbf{R}$. 2001. Induction of systemic resistance in rice against sheath blight disease by Pseudomonas fluorescens. Soil Biology and Biochemistry, $33,603-612$. 
Impact of plant growth-promoting Rhizobacteria on cowpea growth performance and root diseases controlling under greenhouse conditions

Nandi, S., Adhikari, A., Dutta, S., Chattopadhaya, A. and Nath, R. 2013. Potential effects of plant growth promoting rhizobacteria (Pseudomonas fluorescens) on cowpea seedling health and damping off disease control. African Journal of Biotechnology. 12(15),1853-1861.

Niranjan, S., Raj, H.S. and Reddy, M.S. 2005. Plant growth promoting rhizobacteria: Potenial green alternative for plant productivity. Z.A. Siddiqui (ed.), PGPR: Biocontrol and Biofertilization, pp. 197-216.

Nour, K.A.M. and Tolba, H.I. 2015. Evaluation Impact of Some Plant Growth Promoting Microorganisms on the Growth. Middle East Journal of Agriculture. 4(3), 532-544.

Ouziad, F., Wilde, P., Schmelzer, E., Hildebrandt, U. and Bothe, H. 2006. Analysis of expression of aquaporins and $\mathrm{Na}+/ \mathrm{H}+$ transporters in tomato colonized by arbuscular mycorrhizal fungi and affected by salt stress. Environ. Exp. Bot., 57(1), 177-186.

Page, A.L., Miller, R.H. and Kenney, D.R. 1982. Methods of Soil Analysis. Chemical and Microbiological Properties, Part 2, pp. 39- 41. SSSP, Inc., Madison, Wisconsin, USA.

Pallai, R. 2005. Effect of plant growthpromoting rhizobacteria on canola (Brassica napus L.) and lentil (Lens culinaris medik.) plants. M.Sc. Thesis, Sasskatoon Canada.

Pankaj, K.; Satyajeet, K. and Dubey, R.C. 2012. Diversity of Bacilli from Disease Suppressive Soil and their Role in Plant Growth Promotion and Yield Enhancement. New York, USA, Science J., 5 (1), 90- 111.

Parmar, N. and Dadarwal, K. 1999. Stimulation of nitrogen fixation and induction of flavonoid-like compounds by rhizobacteria. Journal of Appied Microbiology, 86, 36-44.

Pathma, J. and Sakthivel, N. 2012. Microbial diversity of vermicompost bacteria that exhibit useful agricultural traits and waste management potential. Department of Biotechnology School of Life Sciences, Pondicherry University, Kalapet, Puducherry 605014, India Springer Plus, pp. 1- 26.

Paulitz, T.C., Zhou, T. and Rankin, L. 1992. Selection of rhizosphere bacteria for biological control of Pythium aphanidermatum on hydroponically grown cucumber. Biol. Control, 2, 226-237.

Paungfoo-Lonhienne, C., Redding, M., Pratt, C., and Wang, W. 2019. Plant growth promoting rhizobacteria increase the efficiency of fertilisers while reducing nitrogen loss. Journal of Environmental Management, 233, 337341.

Ponmurgan, P. and Gopi, C. 2006. In vitro production of growth regulators and phosphatase activity by phosphate solubilizing bacteria. African J. Biotechnology, 5(4), 348-350.

Pozo, M.J. and Azcon, A.C. 2007. Unraveling mycorrhiza-induced resistance. Curr. Opin. Plant Biol., 10, 393-398.

Ramamoorthy, V., Viswanathan, R., Raguchander, T., Prakasam, V. and Samiyappan, R. 2001. Induction of systemic resistance by plant growth promoting rhizobacteria in crop plants against pests and diseases, Crop Prot., 20, 111.

Ryan, M.H. and Angus, J.F. 2003. Arbuscular mycorrhizae in wheat and field pea crops on a low $P$ soil: increased $Z n$-uptake but no increase in P-uptake or yield. Plant Soil., 250, 225-239.

Sahebani, N. and Hadavi, N. 2008. Biological control of the root-knot nematode Meloidogyne javanica by Trichoderma harzianum. Soil biology and biochemistry, 40(8), 2016-2020.

Sasirekha, B.; Srividya, S. and Shanker, B. S. (2012): Identification of multi-trait PGPR isolates and evaluation of their potential as biocontrol agents. Research Article, Acta Biologica Indica, 1(1), 61-67.

Sendhilvel, V., Buvaneswari, D., Kanimozhi, S., Mathiyazhagan, S.K. and Raguchamder, T. 2005. Management of cowpea root rot caused by Macrophomina phaseolina (Tassi) Goid using plant growth promoting rhizobacteria. Journal of Biological- Control., 19(1), 41-46.

Shabaev, V.P., Olyunina, L. N. and Smolin, Y. Y. 1999. Functional activity of maize roots after inoculation with growth promoting rhizosphere bacteria, Pseudomonas. Biological Bulletin of Russian Academic Science, 26, 30-35.

Shalaby, A.M. 2001. Response of rhizospheric microflora and growth of tomato plants to the interaction between arbuscular mycorrhizal fungus Glomus mosseae and Azospirillum lipoferum. Egyptian J. Microbiol., 36(4), 363376.

Shukla, A.K. 2019. Chapter One- Ecology and Diversity of Plant Growth Promoting Rhizobacteria in Agricultural Landscape. In: Singh K.A., Kumar A., \& Singh P.K. (eds.), PGPR Amelioration in Sustainable Agriculture pp.1-15.

https://doi.org/https://doi.org/10.1016/B978-0-12815879-1.00001-X. 
Snedecor, C.W. and Cochran, W.G. 1989. Statistical Methods. $7^{\text {th }}$ Ed. lowa Stat Sci., 20(1-2), 81-84.

Talaat, N.B. and Abdallah A.M. 2008. Response of Faba Bean (Vicia faba L.) to Dual Inoculation with Rhizobium and VA Mycorrhiza under Different Levels of $\mathrm{N}$ and $\mathrm{P}$ Fertilization. J. Appl. Sci. Res., 4, 1092-1102.

Tarrad, A. M.; EL-Hyatemy, Y.Y. and Omer, S.A. 1993. Wyeron derivatives and activities of peroxdase and phenol oxidase in faba bean leaves as induced by chocolate spot disease. Plant Sci., 89, 161-165.

Thahir, B.S., Radhaiah, A., Nagalakshmi, D.M. and Eswara, R.N.P. 2012. Biocontrol potential of indigenous Pseudomonas spp. against Sclerotium rolfsii causing stem rot of groundnut. Int. J. Food Agri. Vet. Sci., 2(1), 134 -141.

Tharne, C., Nielsen, T.H., Nielsen, M.N., Sørensen, J. and Olsson, S. 2000. Viscosinamide producing Pseudomonas fluorescens DR54 exerts a biocontrol effect on Pythium ultimum in sugar beet rhizosphere. FEMS Microbiol. Ecol., 33, 139-146.

Tonelli, M.L., Furlan, A., Taurian, T. Castro, S. and Fabra, A. 2011. Peanut priming induced by biocontrol agents. Physiol. Mol. Plant. Pathol., 75, 100-105.

Va'zquez, M.M., Ce'sar, S., Azco'n, R. and Barea, J. M. 2000. Interactions between arbuscular mycorrhizal fungi and other microbial inoculants (Azospirillum, Pseudomonas, Trichoderma) and their effects on microbial population and enzyme activities in the rhizosphere of maize plants. Appl. Soil Ecol., 15(3), 261-272.

Van Loon, L.C. and Glick, B.R. 2004. Increased plant fitness by rhizobacteria. In: Sandermann $\mathrm{H}$., ed. Molecular ecotoxicology ofplants. Berlin: Springer; pp. 177-205.

Vincent, J. M. 1970. A manual for the practical study of the root- nodule bacteria. "IBP Handbook No. 15. Black well Sci., Pul. Oxford and Edinburgh. pp. 54-58.
Vivekananthan, R., Ravi, M., Ramanathan, A. and Samiyappan, R. 2004. Lytic enzymes induced by Pseudomonas fluorescens and other biocontrol organisms mediate defence against the anthracnose pathogen in mango. World $\mathbf{J}$. Micro Biotech., 20, 235-244.

Whipps, J.M. 2001. Microbial interactions and biocontrol in the rhizosphere. J. Exp. Bot., 52, 487-511.

Xiang, X., Lu, M.W., Haiyan, Z., Ruqian, P., Jiang, T., Shuxian, L. and Hong, L. 2012. CoInoculation with Rhizobia and AMF Inhibited Soybean Red Crown Rot: From Field Study to Plant Defense- Related Gene Expression Analysis.PLoS ONE 7(3), e33977. doi:10.1371 /journal.pone.0033977.

Yehia, A.G., Mohsen M., Ebrahim, K.H. and Ali, M.M. 2004. Influence of some plant extracts and microbioagents on some physiological traits of faba bean infected with Botrytis fabae. Turk. J. Bot., 28, 519-528.

Zaghloul, R. A. 1999. Effectiveness of dual inoculation with Azospirillum and phosphate solubilizing microorganisms on growth and yield of Zea mays L. Zagazig J. Agric. Res., 26(4), 1005-1025.

Zaghloul, R.A., Hanafy, Ehsan, A., Neweigy, N.A. and Khalifa, Neamat, A. 2007. Application of biofertilization and biological control for tomato production. Proc. $12^{\text {th }}$ Microbiology Conf., Cairo, Egypt, pp. 18-20.

Zaghloul, R.A., Rahal, A.G., Neweigy, N.A., Hanafy, E.A. and El-Meihy, R.M. 2008. Efficiency of soil inoculation with growth regulators producing microorganisms on some enzymes activity. $3^{\text {rd }}$ International Scientific Conference for Environment South Valley Univ. Egypt. pp. 1-10.

Zahra, M.K. 1969. Studies of silicate bacteria. M.Sc. Thesis, Fac. Agric., Cairo Univ., Egypt, $111 \mathrm{p}$.

Zayed, M.S., Hassanein, M., Esa, N.H. and Abdallah, M. 2013. Productivity of pepper crop (Capsicum annuum L.) as affected by organic fertilizer, soil solarization, and endomycorrhizae. Ann. Agric.. Sci., 58(2), 131-137. 


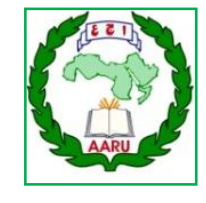

المؤتمر الرابع عشر لبحوث التننمية الزراعية،

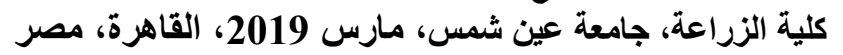

مجلا(27)، عدد(1)، عداد خاص مارس، مارس 257-239، 2579 2019

Website: http://strategy-plan.asu.edu.eg/AUJASCl/

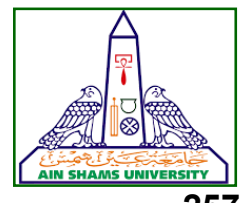

تأثير البكتيريا المشجعة لنمو النبات علي نمو اللوبيا ومقاومة أمراض الجذور

[22]

راشد عبد الفتاح زغلول1 - حامد السيد أبو على1 - هانى محمد عبد الرحمن 1 -

مخلص عديل حسن 2

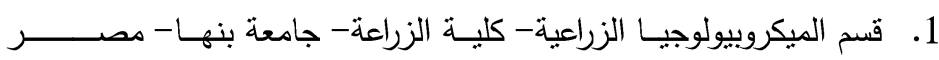

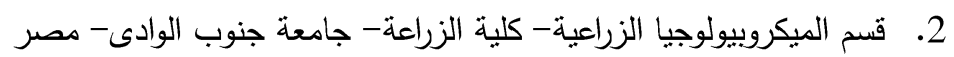

Received 3 February, $2018 \quad$ Accepted 14 April, 2019

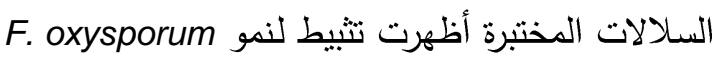

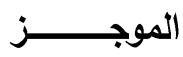

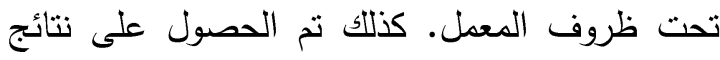

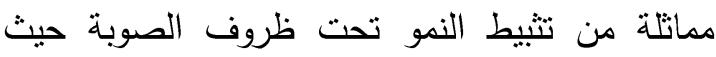

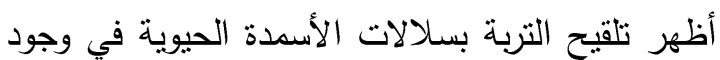

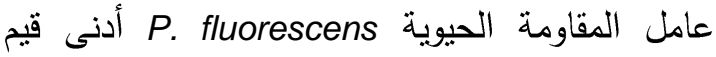
للنبة الإصابة، كما سجلت أعلي القية القيم للأنشطة

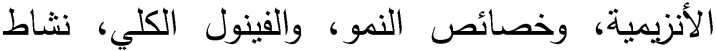

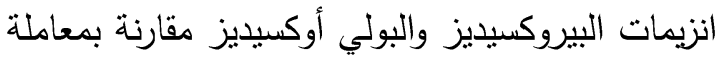

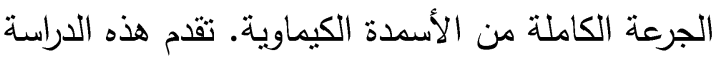

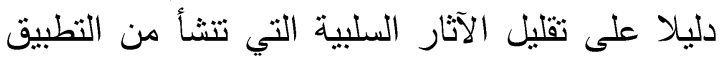

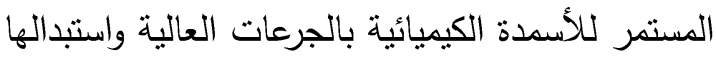
(جزئيا على الأقل) من خلال الأسمدة الحيوية وعوامل لئل الئل

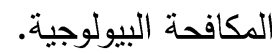

الكلمات الدالة: اللوبيا، البكتبريا المشجعة لنمو النبات، أمراض الجذور، ظروف الصوبة الصية الصيات

أجريت تجربتان خلال موسمين منتاليين 2014 و2015 في كلية الزراعة جامعة جنوب الوناب الوادي

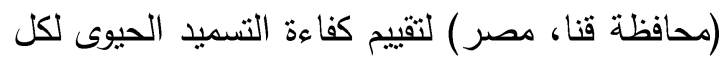
Bradyrhizobium sp, Bacillus megaterium si var. phosphaticum, Bacillus circulans, Glomus وكذللك البكتيريا المستخدمة في macrocarpum المقاومة الحيوية هن جنس بseudomonas fluorescens

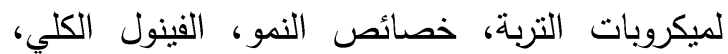
نشاط انزيم البيروكسيديز والبولي فينول أوكسيديز في الفي الفئول

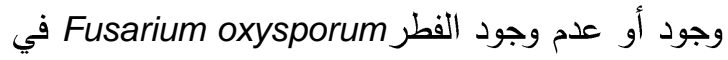

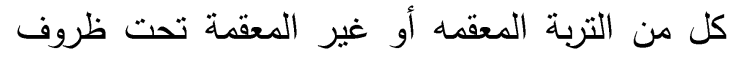

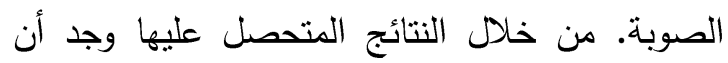

